
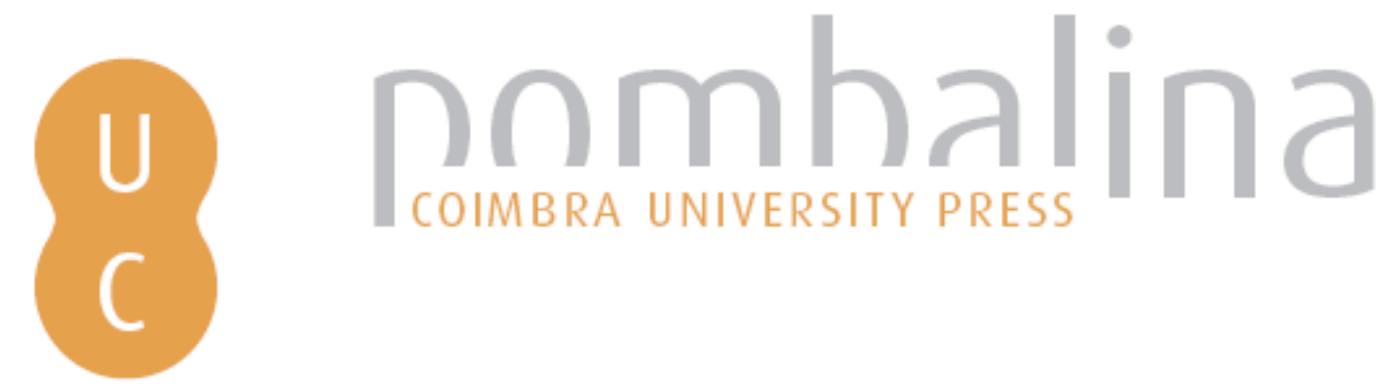

\title{
Los detentores de la verdad absoluta: la imagen de Salazar y Franco ante la sociedad portuguesa: radiografía de algunos tópicos esenciales
}

Autor(es): $\quad$ Pena Rodríguez, Alberto

Publicado por: Imprensa da Universidade de Coimbra

URL

persistente: URI:http://hdl.handle.net/10316.2/36644

DOI: $\quad$ DOI:http://dx.doi.org/10.14195/978-989-26-0873-0_5

Accessed : $\quad$ 26-Apr-2023 14:25:54

A navegação consulta e descarregamento dos títulos inseridos nas Bibliotecas Digitais UC Digitalis, UC Pombalina e UC Impactum, pressupõem a aceitação plena e sem reservas dos Termos e Condições de Uso destas Bibliotecas Digitais, disponíveis em https://digitalis.uc.pt/pt-pt/termos.

Conforme exposto nos referidos Termos e Condições de Uso, o descarregamento de títulos de acesso restrito requer uma licença válida de autorização devendo o utilizador aceder ao(s) documento(s) a partir de um endereço de IP da instituição detentora da supramencionada licença.

Ao utilizador é apenas permitido o descarregamento para uso pessoal, pelo que o emprego do(s) título(s) descarregado(s) para outro fim, designadamente comercial, carece de autorização do respetivo autor ou editor da obra.

Na medida em que todas as obras da UC Digitalis se encontram protegidas pelo Código do Direito de Autor e Direitos Conexos e demais legislação aplicável, toda a cópia, parcial ou total, deste documento, nos casos em que é legalmente admitida, deverá conter ou fazer-se acompanhar por este aviso.

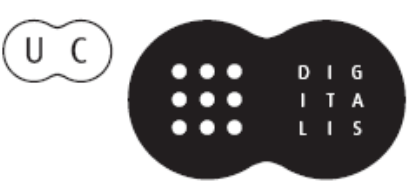


www.uc.pt/ imprensa_uc CONTACTO imprensa@uc.pt VENDAS ONLINE http://livrariadaimprensa.uc.pt JANEIRO 2015
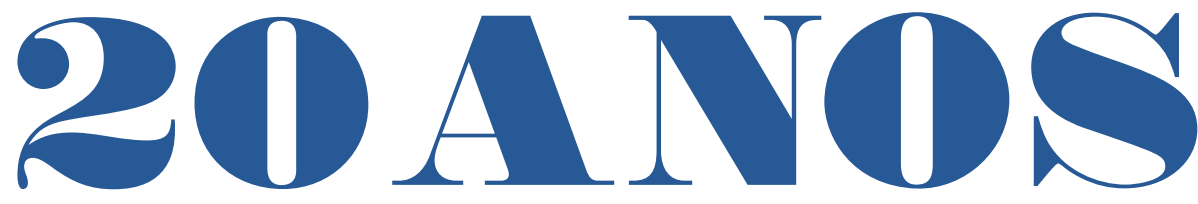

\section{DE JORNALISMO CONTRA A INDIFERENÇA}

TEXTOS DE

Marc Lits, Adriano Duarte Rodrigues, Tito Cardoso e Cunha, José Augusto Mourão, Alberto Pena Rodríguez, Maria Augusta Babo, Daniel Cronu, João Pissarra Esteves, Gilles Gauthier, Heloísa Paulo e Luís Reis Torgal, Alfredo Barroso, António Fidalgo, Nöel Nel, João de Almeida Santos, Juan Luis Cebrián, António Dias Figueiredo, Marina Themudo, Jorge Sampaio, Nelson Traquina, Mário Soares
( livro que agora se apresenta, nasce de dois desígnios fundamentais: por um lado, celebrar duas décadas de ensino do Jornalismo na Universidade de Coimbra e, por outro, partilhar com um público mais alargado um conjunto de reflexões sobre os media, o jornalismo, a comunicação e o espaço público.

Se o ensino superior do Jornalismo em Portugal, relativamente tardio em relação ao resto da Europa, deu os seus primeiros passos no fim dos anos 70 do século passado, ele aparece apenas duas décadas depois na academia coimbrã. Contudo, esta foi, no contexto nacional, a primeira licenciatura em Jornalismo, distinguindo-se, quer em título, quer em objetivos, das licenciaturas então existentes no país. A criação de uma Licenciatura em Jornalismo na Universidade de Coimbra, em 1993-1994, foi, por si, um acontecimento. Com efeito foi necessário que reitor, professores e jornalistas ousassem atualizar a oferta curricular da Faculdade de Letras, oferecendo um curso há muito desejado pela sociedade e pelo mercado, embora desconsiderado por alguns setores da academia. Correndo o risco de omitir alguém, a quem antecipadamente pedimos desculpa, não podemos deixar de recordar os esforços dos jornalistas João Mesquita, João Fonseca, em representação
Todas as gerações, sem dúvida, se julgan para refazer o mundo. A minha sabe, nc que não poderá refazê-lo. A sua tarefa é tc

Consiste em impedir que se desfaça, $p$ unicamente das suas negações A. Camus, Discursos da Suécia (1957)

do Sindicato dos Jornalistas, e de Jorge Castilho, a quem mais tarde se viria associar o nome de Mário Martins, bem como o do então Reitor da Universidade de Coimbra Rui Alarcão, e dos professores João Roque e Luís Reis Torgal. Entre 1993 e 1996, a Licenciatura em Jornalismo funcionou com um Secretariado, que teve um papel executivo e científico nos primeiros tempos do curso na FLUC. Presidido pelo Presidente do Conselho Científico Ludwig Scheidl, este 


\title{
Los Detentores de la Verdad Absoluta \\ La imagen de Salazar y Franco ante la sociedad portuguesa. Radiografía de algunos tópicos esenciales
}

\author{
Alberto Pena Rodríguez \\ Universidade de Vigo \\ Faculdade de Ciências Sociais
}

\section{Breve introducción}

El estudio de la imagen de los dos dictadores peninsulares en los medios de comunicación de los respectivos países está todavía por hacer. Como están pendientes de un abordaje científico muchas de las facetas propagandísticas del salazarismo en sus diversas etapas históricas (Segunda Guerra mundial, guerra fría o guerra colonial, entre otras). ${ }^{1}$ De hecho, actualmente, la propaganda política del salazarismo es uno de los aspectos importantes a los que los investigadores portugueses no le han prestado suficiente interés, quizás porque hay tareas más importantes en las que invertir el esfuerzo de la investigación, o porque todavía no hay suficientes profesionales de las Ciencias de la Información especializados en este campo. Sea como fuere, el hecho es que faltan estudios específicos o generalistas sobre el papel de la comunicación social en Portugal durante la dictadura de Oliveira Salazar, ${ }^{2}$ que proba-

${ }^{1}$ El Prof. Luis Reis Torgal ya reclamó en varias ocasiones la atención de los investigadores sobre la necesidad de abordar el estudio de la dictadura portuguesa de una manera parcelada, especializada, y profesional para crear un corpus bibliográfico suficiente que permita hacer estudios más generales. Cf.: Torgal, Luis Reis, "Sobre a Historia no Estado Novo. Fontes, bibliografia, áreas de abordagem e problemas metodológicos", in Revista de História das Ideias, n 14, Coimbra, Faculdade de Letras, 1992, pp. 529-554.

${ }^{2}$ El único libro especializado publicado en relación con este tema es el libro de Heloísa Paulo, Estado Novo e Propaganda em Portugal e no Brasil. O SPN/SNI e o DIP, Coimbra, Minerva, 1994, cuya tesis doctoral titulada Aquí também é Portugal. A imagem de Salazar na colónia portuguesa de Brasil, dirigida por el Prof. Luis Reis Torgal y defendida en diciembre de 1997 en la Universidad de Coimbra, sienta las bases para los futuros estudos sobre la propaganda política salazarista. Paulo publicó, además, un interesante artículo sobre la imagen de Salazar a través del estudio de las biografías publicadas sobre su persona que hace una aportación importante en el contexto de este artículo sobre la propaganda política del salazarismo. Cf.: Paulo, Heloisa, "Salazar; a elaboração de uma imagem”, in Revista de História das Ideias, Coimbra, Faculdade de Letras, $n^{\circ}$ 18, pp. 245-275. También pueden consultarse las siguientes obras: Torgal, Luis Reis, Ideologia, Cultura e mentalidade no Estado Novo. Ensaios sobre a Universidade de Coimbra, Coimbra, Faculdade de Letras, 1993; Martins, Moisés de Lemos, O olho de Deus no discurso salazarista, Porto, Edições 
blemente le corresponda hacer a los investigadores que trabajan en las licenciaturas relacionadas con el área de la Comunicación Social en Portugal.

En este sentido, nuestra modesta investigación no es más que una propuesta de acercamiento, una ligera pincelada en el cuadro general de ambas dictaduras peninsulares, con un perspectiva totalmente histórica, pero que pretende extraer algunas conclusiones (nuca definitivas) sobre las técnicas del discurso propagandístico del salazarismo y la manera en que se forjó la imagen de ambos líderes autoritarios en los años en que se decidía, en el caso portugués, la consolidación del Estado Novo, y en el español, la creación de un nuevo sistema político impuesto por la fuerza de las armas.

Este artículo pretente, simplemente, poner el acento sobre algunos de los aspectos más interesantes y más tópicos en la construcción que la prensa portuguesa hizo de la imagen de Franco y Salazar en la segunda mitad de los años treinta, durante uno de los momentos en los que la maquinaria propagandística del Estado Novo fue más activa: la Guerra de España (1936-1939). Con esta clara delimitación temporal, no es, obviamente, nuestro propósito en este sucinto trabajo hacer un exhaustivo estudio de la imagen de ambos dictadores a través de la prensa portuguesa, sino más bien rescatar del amarillecido papel de los periódicos algunas de las consignas más indelebles y datos reveladores que forjaron la imagen de Franco y Salazar.

\section{Salazar, el redentor de Portugal}

La visión que ofrece la prensa portuguesa de aquellos trágicos años para los españoles, cuya desgracia se transformó en un imborrable recuerdo para los portugueses, es, paradójicamente, la imagen de una tempestad que trae la gloria y la paz. Era un período de penitencia para la Península en proceso hacia el alumbramiento de una nueva etapa triunfal, bajo la batuta de nuevos líderes, fuertes, capaces e imperialistas, según el punto de vista de la propaganda oficial. En medio de los campos de ceniza y muerte que se extendían por España se estaba gestando un nuevo mundo y Portugal estaba a la cabeza. Salazar era su mesías.

La prensa lusa construye una imagen mítica y endiosada dell dictador portugués, ${ }^{3}$ que aparece en las páginas de los periódicos como un héroe entre

Afrontamento, 1990; União Nacional, Projecção de Salazar no estrangeiro, Porto, 1949. ${ }^{3}$ Para acercarse a la personalidad de ambos dictadores peninsulares, sus manías, sus similitudes y las circunstancias de sus encuentros oficiales cf.: Medina, João, "Salazar e Franco. Dois ditadores, duas ditaduras”, in revista História, ano XVIII, nova série, $\mathrm{n}^{\circ} 20$, Lisboa, maio de 1996, pp. 4-15. 
los héroes, sabio infalible y redentor de Portugal del que todos los portugueses sienten orgullo porque es el nuevo "descubridor"; su prestigio, según cuentan los editoriales, ha hecho renacer el "espirito civilizador" de su país. ${ }^{4}$ La constante publicación de noticias y comentarios que hacen imprescindible e insustituíble su presencia en el gobierno como Presidente do Conselho, tenía como objetivo agrupar a todos en torno a él, evitar las disidencias y las fricciones internas en el momento más crítico desde la instauración del Estado Novo, justo cuando en España estalla un intento de derrumbar el orden democrático establecido para instaurar un régimen fascista. Salazar tenía muy claro lo que quería, y lo que deseaba era que en España triunfase el Movimiento que acabaría con la II ${ }^{a}$ República y, con ello, el posible contagio democrático de Portugal. ${ }^{5}$

Cada una de las decisiones políticas del dictador portugués, de sus propuestas sociales, de sus frases, era una lección, era "a lição de Salazar". ${ }^{6}$ Sus palabras se revestían siempre de un halo divino. ${ }^{7}$ Llegó hasta tal punto la propaganda sobre el prestigio de su persona que el órgano de la União Nacional y la Emissora Nacional organizaron, en marzo de 1937, un concurso nacional sobre las frases más brillantes de Salazar con el fin de divulgar el "pensamento nacionalista" del dictador. Los medios de comunicación salazaristas hicieron una campaña sin precedentes del concurso, distribuyendo carteles (incluso de forma aérea) $)^{8}$ por todas las ciudades y pueblos del país encabezados por las leyendas "Ouvir a Emissora Nacional" y "Ler o Diário da Manhã", bajo las cuales se reproducía un perfil de Salazar realizado por el pintor Eduardo

\footnotetext{
${ }^{4}$ Diário da Manhã, n ${ }^{\circ}$ 2408, 04/01/1938, p. 1.

${ }^{5}$ Son ya muchas las obras y los artículos que han tratado este asunto. Citaremos algunas referencias bibliográficas importantes: Oliveira, César, Salazar e a Guerra Civil de Espanha, Lisboa, O Jornal, $2^{\text {a }}$ edição, 1987; idem, Portugal e a II República de Espanha, Lisboa, Perspectivas \& Realidades, s.d.; Delgado, Iva, Portugal e a Guerra Civil de Espanha, Lisboa, Publicações Europa-América, (1980); Rosas, Fernando, O salazarismo e a aliança luso-britânica, Lisboa, Fragmentos, 1988; AA.VV., Portugal e a Guerra Civil de Espanha, Lisboa, Câmara Municipal, 1996; Torre Gómez, Hipólito de la, La relación peninsular en la antecámara de la guerra civil de España (1931-1936), Mérida, Uned, s.d. Entre otras.

${ }^{6}$ O Século, ${ }^{\circ}$ 20154, 27/04/1938, p. 5. Sobre las celebraciones nacionales al cumplirse el $10^{\circ}$ aniversario de la llegada al poder de Salazar, cf.: Aguiar, Alda M. Vaz Martins, con Tomé, Carlos Manuel da Silva, y Morais, Violeta de Oliveira, “A “Lição de Salazar”", in revista História, Lisboa, $\mathrm{n}^{\circ}$ 83, novembro de 1984, pp. 3-15.

${ }^{7}$ Cf.: Martins, Moisés de Lemos, O Olho de Deus no discurso salazarista, Porto, Edições Afrontamento, 1990.

${ }^{8}$ Diário da Manhã, nº 2134, 31/03/1937, p. 8.
} 
Malta y el reclamo "Grande Concurso Nacional". Para adquirir la condición de concursante era necesario oir y leer diariamente los dos medios públicos durante dos meses, en busca de las frases más lúcidas del dictador. ${ }^{10}$ En total, participaron 7.623 personas, que tuvieron que escoger y votar por la jaculatoria que creían más representativa de la patrótica sabiduría de Salazar. (En el anexo final de este trabajo recogemos las 60 frases que había que recopilar para participar en el concurso). Se anunciaron grandes premios para los vencedores, entre ellos un coche y cientos de regalos donados por innumerables casas comerciales. Los premios tenían varias categorías divididos entre amas de casas (cuyo mejor obsequio era una máquina de coser), obreros (un seguro de vida), oficinistas (una máquina de escribir), estudiantes (un traje académico y gratuidad de tasas) y funcionarios (18 días de vacaciones en los mejores hoteles de Portugal). ${ }^{11}$

${ }_{9}$ Diário da Manhã, ${ }^{\circ}$ 2125, 21/03/1937, p. 1. Sobre la imagen de Salazar a través de los carteles de propaganda, cf.: Rosas, Fernando, Cartazes de Propaganda Política do Estado Novo, Lisboa, Biblioteca Nacional, 1988; Janeiro, Helena, y Alarcão e Silva, Isabel, in revista Vértice, II série, Lisboa, ${ }^{\circ}{ }^{13}$, abril de 1989, pp. 63-69.

${ }^{10}$ Las instrucciones para poder concursar fueron publicadas numerosas veces por el Diário da Manhã y emitidas por la Emissora Nacional. Estas decían lo siguiente: $1^{\circ}$ - Comprar o "Diário da Manhã". $2^{\circ}$ - Cortar a frase de Salazar que será publicada no texto do jornal e, também, o cupão respectivo. $3^{\circ}$ - Colar a frase e o cupão na caderneta. $4^{\circ}$ - Registar uma das horas a que se ouviu a Emissora Nacional, repetir a frase publicada nesse dia. (A Emissora repete a frase: - de manhã, no noticiário das 12 e 30; de tarde, no noticiário das 19 horas e 50; à noite, no noticiário das 22 horas e 30 e, ainda, às 24 horas, no fecho da estação). O locutor, antes e depois de repetir a frase, dirá a hora. Nas localidades onde, por acaso, falta a energia eléctrica, como muitas vezes sucede, o concorrente registará: - não ouvi por interrupção da corrente. $5^{0}$ - Terminada a coleç̧ão das sessenta frases de Salazar que vão ser publicadas no "Diário da Manhã" escolher aquela que the parecer de mais elevado sentido nacionalista e registar na capa da caderneta o número que lhe competir na referida colecção.

$6^{\circ}$ - Preencher a capa da caderneta com o nome, morada e profissão. $7^{\circ}$ - Entregar a caderneta na Administração do "Diário da Manhã" ou na Emissora Nacional. (Os concorrentes da província devem remetê-las registadas). $8^{\circ}$ - Receber em troca uma senha com número idêntico àquele que fôr posto na mesma caderneta. $9^{\circ}$ - Esperar pelo sorteio que pode proporcionar-lhe três prémios: - um da categoria geral; outro que será sorteado entre os votantes da frase escolhida e, ainda, um terceiro, o da profissão.

Os concorrentes da Madeira, Açores, Cabo Verde, Guiné, S. Tomé e Príncipe, Angola, Moçambique, Índia,Brasile América do Norte ouvirão a frase de Salazarna emissão de ondas curtas. Ela será sempre repetida à hora do noticiário e este consta sempre dos respectivos programas daquela emissão. Simplesmente, os concorrentes do estrangeiro e da Madeira (...) (colonias repetidas arriba) ficam habilitados, coleccionando apenas 30 frases à escolha, ao contrário dos concorrentes do continente que terão de coleccionar as sessenta frases publicadas." (cursiva en el original). Cf.: Diário da Manhã, nº 2125, 21/03/1937, p. 1.

${ }^{11}$ Diário da Manhã, nº 2125, 21/03/1937, p. 1. 
La frase más votada fue "Nada contra a Nação, tudo pela Nação", que casualmente era el subtítulo del Diário da Manhã y estaba inspirada en el pensamiento fascista italiano. Resultó elegida por 5.982 concursantes. ${ }^{12}$ Sus mejores 200 máximas, además, fueron publicadas en un libro de edición inglesa por el SPN con un retrato del dictador. ${ }^{13}$ La venta de retratos suyos estaba al orden del día entre los afiliados de la Legião Portuguesa y la Mocidade Portuguesa, y la prensa portuguesa publicaba anuncios que recordaban que la "bela estampa do eminente chefe Salazar" se podía comprar en cualquier librería. ${ }^{14}$

Esta es un prueba más de la feroz propaganda que, en general, los medios de comunicación portugueses realizaban del fundador del Estado Novo. Evidentemente, se trataba de una natural respuesta del régimen para blindar el poder y defender la estabilidad del gobierno en torno a la entronada e indiscutible figura de su líder, pero también hay una clara influencia del culto fascista al Jefe, alrededor del cual se crea una jerarquía corporativa y una estratificación social. Y todo porque, según apunta el órgano del gobierno dictatorial luso “(...) estamos num tempo em que aqueles que defendem uma ideologia política de salvação e engrandecimento nacional precisam de fazer propaganda intensa e contínua dos seus princípios e convicções, como meio de defesa própria, de esclarecimento alheio e de oposição a propagandas contrárias de doutrinas desnacionalizadoras (...)". ${ }^{15}$

Claro que esta propaganda personalista del salazarismo supo aprovecharse muy bien de los acontecimientos trágicos de España para resaltar el valor de la obra de Salazar. Estrategia que llevaría a establecer una inevitable relación entre los éxitos militares y sociales del franquismo (sic) y la dictadura portuguesa. La propaganda del Estado Novo afirmaba que la fortaleza política y económica que Salazar había conseguido para Portugal antes de julio de 1936, permitió que la transformación de España que reivindicaban los rebeldes fuese posible gracias al dictador portugués, verdadero artífice y garantía de éxito para el triunfo militar sobre los “comunistas" españoles (sic), tal y como afirmaba el editorial del Diário da Manhã al cumplirse un año del estallido del golpe bajo el título "Resurreição de Espanha":

“(...) Como portugueses, não esqueçamos que se à Espanha verdadeira e nobre foi possível reerguer-se e caminhar isso se deve a existência neste canto do ocidente da Península de um Portugal tranquilo e firme, segu-

\footnotetext{
${ }^{12}$ Idem, n ${ }^{\circ} 2240,16 / 07 / 1937$, p. 3-5.

${ }^{13}$ Diário de Notícias, $\mathrm{n}^{\circ}$ 26319, 18/05/1939, p. 1.

${ }^{14}$ O Século, no 20186, 30/05/1938, p. 12.

${ }^{15}$ Idem, ${ }^{\circ} 2184,21 / 05 / 1937$, p. 1.
} 
ra garantia de que a fogueira não podia alastrar, exemplo bem digno de seguir, capaz de encorajar e de animar. Só assim seremos justos para nós próprios, só assim mostraremos ao Mundo, que nos admira, que somos gratos ao Chefe que nos dirige e nos comanda, que somos, como Povo, bem dignos de tal Chefe. Orgulhosos da nossa força, que não é afrontosa para ninguém, e do nosso prestígio, conquistado alegremente com pequenos sacrifícios bem compensados, estaremos melhor para louvarmos quantos têm marcado por seu esforço admirável e heróico na defesa da Civilização.”.

Oliveira Salazar se transforma en el guía nacional, desarrollando una "genial” política internacional respecto de la Guerra Civil. Según el órgano de la União Nacional, con su perspicacia diplomática, el Presidente do Conselho consiguió adoptar la posición más digna y conveniente para su país y para España. ${ }^{17}$ Tras las revueltas internas más graves contra el gobierno autoritario luso durante la guerra, el 8 de septiembre de 1936, el 20 de enero de 1937 y el 4 de julio de este mismo año, ${ }^{18}$ hechos que la propaganda oficial relacionó directamente con los “comunistas" españoles, la figura de Salazar salió fortalecida. El Diário de Notícias fue meridianamente claro en esa asociación propagandística en su editorial del 21 de enero de 1937: “(...) A Península Ibérica é hoje um campo de batalha e Portugal, quer o queiram quer não os covardes e os traidores, constitui agora a retaguarda de um exército em campanha (...)". ${ }^{19}$ Con un mensaje puramente nacionalista, se colocaba al dictador como víctima de una persecución del comunismo internacional, que pretendía derrocarlo por todos los medios sin éxito. Según Salazar, los verdaderos agitadores del país eran los agentes españoles al servicio del bando leal que pretendían exportar la guerra a Portugal..$^{\circ}$ El momento que más explotó propagandísticamente el régimen para encumbrar definitiva-

\footnotetext{
${ }^{16}$ Idem, $\mathrm{n}^{\mathrm{0}} 2242,18 / 07 / 1937$, p. 1.

${ }^{17}$ Idem, $n^{\circ}$ 2150, 16/04/1937, p. 3 .

${ }^{18}$ El 8 de septiembre de 1936 se produjo la revuelta de los marineros de los tres barcos de guerra portugueses, el Afonso de Alburquerque, Bartomoleu Dias y el Dão. El 20 de enero de 1937, ocurrió el atentado anarquista contra varios edificios del gobierno o empresas privadas de Lisboa que colaboraban con los rebeldes españoles, entre ellos el Ministério do Interior, la Emissora Nacional y el Rádio Club Português. Por último, el 4 de julio de 1937 los anarquistas volvieron a atentar, esta vez contra el mismísimo Oliveira Salazar, que salió ileso.

${ }^{19}$ Diário de Notícias, ${ }^{\circ}$ 25489, 21/01/1937, p. 1.

${ }^{20}$ Cf.: Diário da Manhã, nº 1940, 11/09/1936, p. 1 .
} 
mente la figura de un Salazar odiado por el reviralhismo, según las consignas oficiales, por su independencia y por sus virtudes como gobernante, fue el atentado con bomba que los anarquistas portugueses cometieron contra él el 4 de julio de 1937 en Lisboa. João Silvestre manifiesta en A Voz que la bomba contra el dictador llevaba el sello del gobierno español: “(...) É o mesmo que estão fazendo os vermelhos de Madrid no ataque às posições nacionalistas da cidade universitária. É o que fizeram em Carabanchel e o que também fazem em Bilbau para que fôsse pelos ares da cidade, à entrada das tropas nacionalistas (...) Quem ensinou estas artes aos vermelhos de Madrid devem ter sido os mesmos mestres que as ensinaram aos conspiradores de Lisboa (...)". ${ }^{21}$

Durante varias semanas, la prensa portuguesa fue un clamor de felicitaciones a Salazar por su suerte divina. A Voz estaba convencida, al igual que otros diarios, que el dictador contó con la protección de Dios porque su misión política era trascendental para el mundo. Su vida “(...) não pertence apenas ao homem a quem Deus concedeu: pertence à Nação. Importa por isso que se defenda como tal (...). O sr. dr. Salazar é hoje, não apenas um defensor da Ordem em Portugal, mas um defensor da Ordem na Europa. O seu desaparecimento seria uma manifesta vantagem para a Horda sinistra que por toda a parte faz sentir os seus manejos criminosos e para toda a parte expede os seus agentes (...)", aseveraba el diario lisboeta. ${ }^{22}$ Por iniciativa de los organismos corporativos del Estado Novo, se sucedieron las manifestaciones populares en diferentes puntos del país y a la residencia del dictador acudieron en riada miles de personas a dejar flores y felicitaciones, ${ }^{23}$ mientras la Iglesia Católica celebraba incontables ceremonias religiosas en honor de Salazar. ${ }^{24}$ El 5 de julio por la noche, un nutrido grupo de miembros de la Legião Portuguesa y de la Mocidade Portuguesa constituyeron una improvisada comisión de agradecimiento a los periódicos nacionalistas por su actitud de rechazo contra el acto terrorista y su campaña anti-comunista. ${ }^{25}$ La comisión recorrió las redacciones de los diarios lisboetas O Século, A Voz, Diário de Notícias, Diário da Manhã, y de la Emissora Nacional y el Rádio Club Português. Por otra parte,

\footnotetext{
${ }^{21} A$ Voz, $\mathrm{n}^{\mathrm{o}} 3724$, 08/07/1937, p. 1.

${ }^{22}$ A Voz, $\mathrm{n}^{\mathrm{o}} 3721,05 / 07 / 1937$, p. 1.

${ }^{23}$ Cf.: O Século, ${ }^{\circ} 19865,06 / 07 / 1937$, pp. 1 y 2.

${ }^{24}$ Cf.: Idem, n ${ }^{\circ}$ 19867, 08/07/1937, p. 2; idem, nº 19868, o9/07/1937, pp. 1 y3; idem, nº 19870, 11/07/1937, pp. 1 y 2; idem, nº 19871, 12/07/1937, pp. 1 y 5.

${ }^{25}$ Idem, n ${ }^{\circ}$ 19865, 06/07/1937, p. 6. Los miembros de la comisión eran los siguientes. Por parte de la Legião Portuguesa estaban: Júlio dos Anjos Pimentel, Francisco José Ventura, Dámaso Silva, José Correia y Belarmino Sousa Torres. Por parte de la Mocidade Portuguesa: Carlos Pinto da Gama Rosa, António Horta e Costa y Francisco Morais.
} 
varias decenas de oficiales de la Armada acudieron a la Assembleia Nacional para demostrarle la más firme adhesión a la política del Jefe. ${ }^{26}$ El suplemento infantil de $A V o z$ dedicó uno de su números a este asunto, reproduciendo 11 textos de estudiantes donde expresan la condena del atentado y piden la gloria para Salazar. ${ }^{27}$ "Pela segunda vez os que não admitem que em Portugal se viva a vida tranquila e digna dos povos ainda não contaminados pela peste virulentíssima do bolchevismo e do terrorismo tentaram ontem lançar esta terra na confusão e no sangue, para nela desencadearem as tragédias, os crimes, as selvajarias e as inauditas infâmias de que tem sido teatro a pobre Espanha submetida ao império miserável dos vermelhos(...)" ${ }^{28}$ Los fracasos de la oposición, sumados a los relatos periodísticos que hablaban de un Salazar invencible que luchaba por proteger a los portugueses del marxismo y colaborar con los españoles en una cruzada diplomática y propagandística sin cuartel, aumentaron aún más el carisma del líder portugués, convertido en un hombre de hierro con un corazón de oro.

La prensa portuguesa nos informa que esta postura mereció el reconocimiento de medios de comunicación de todo el mundo. Citando expresamente aquellos periódicos de tendencia conservadora o fascista que alaban su política exterior, el Presidente do Conselho es elevado al altar de la fama. ${ }^{29}$

Desde Chile ${ }^{30}$ hasta Alemania, ${ }^{31}$ desde Brasil ${ }^{32}$ hasta Italia, desde Canadáa ${ }^{33}$

\footnotetext{
${ }^{26}$ Idem, n ${ }^{\circ} 19866,07 / 07 / 1937$, p. 1.

${ }^{27} \mathrm{AVoz}, \mathrm{n}^{\mathrm{0}} 3727,11 / 07 / 1937$, suplemento infantil, ano VI, $\mathrm{n}^{\circ} 41$, pp. 2 y3. Sobre la propaganda en la enseñanza de la Historia durante el Estado Novo cf.: Torgal, Luis Reis, História e Ideologia, Coimbra, Minerva, 1989, pp.197-273; Ribeiro, António Manuel, "Ficção histórica infanto-juvenil no Estado Novo. Colecção "Pátria" de Virgínia de Castro e Almeida (1936-1946)", in Do Estado Novo ao 25 de Abril, Revista de História e Teoria das Ideias, vol. 16, Coimbra, Faculdade de Letras, 1994, pp. 161-192. Sobre la enseñanza de la historia durante el franquismo cf:: Martínez-Risco Daviña, Luis, O ensino da hitoria no bacharelato franquista, período 1936-1951), Sada (A Coruña), Ediciós do Castro, 1994; Martínez Tórtola, Esther, La enseñanza de la historia en el primer bachillerato franquista (1938-1953), Madrid, Tecnos, 1996. ${ }^{28}$ O Século, $\mathrm{n}^{\mathrm{o}}$ 19864, 05/07/1937, p. 1.

${ }^{29}$ Diário de Notícias, $\mathrm{n}^{\circ}$ 25363, 13/09/1936, p. 5 .

$3^{30}$ A Voz, $\mathrm{n}^{\circ} 3533,22 / 12 / 1936$, p. 6. El periódico de Fernando de Souza cita un artículo publicado por el ministro de Finanzas chileno, Roberto Mecks, titulado "Salazar, dictador impersonal", diciendo que es "motivo de orgulho para a latinidade". A Voz se refiere también a artículos de intelectuales como el escritor Eduardo Barrios.

${ }^{31}$ O Século, n ${ }^{\circ}$ 19832, 03/06/1937, pp. 1 y 2.

${ }^{32}$ Diário de Notícias, nº 25415, 05/11/1936, p. 4.

33 Diário da Manhã, nº 2078, 31/01/1937, p. 1.
} 
hasta Francia, ${ }^{34}$ desde Polonia ${ }^{35}$ hasta América del Sur ${ }^{36}$ Salazar era admirado por todos. ${ }^{37}$ En palabras del Diário da Manhã el Jefe luso formaba parte del patrimonio europeo:

“(...) Ao seu génio de doutrinário e de construtor; à sua competência de financeiro e de jurista; à sua fé integra e à sua persistência calma; ao seu rigor nos seus métodos e à clarividência dos seus juizos; à sua força de vontade e à sua superior noção do Interesse Nacional; à sua probidade absoluta de administrador e à sua energia inquebrantável de Chefe. Por isso mesmo, o nome de Salazar, o pensamento de Salazar, as reformas de Salazar, fazem parte do mais alto património da civilização europeia. E as homenagens ao Chefe do Governo português acumulam-se, multiplicam-se, traduzem com eloquência o valor universal (cursiva en el original) do seu prestígio. Prestígio de Portugal e prestígio de Salazar - ambos intimamente unidos, numa fórmula sintética de ressurgimento. E o prestígio de Portugal será tanto mais sólido, tanto mais alto, quanto melhor se sinta lá fóra a plena estabilidade do seu Governo, a progressão serena do seu esforço, dentro dos mesmos princípios condutores, sob o mesmo Chefe ilustrado e consagrado no presente pelas mais belas vitórias hão-de continuar e frutificar integralmente, nas jornadas da História futura!.”38

\section{El guía espiritual de Europa}

Los argumentos de los medios de comunicación portugueses, debidamente aleccionados y censurados por el Secretariado de Propaganda Nacional (SPN) transforman a Salazar en un hombre con prestigio y poder suficiente para reivindicar su derecho a influir en el destino de Europa. "A figura de sr. dr. Oliveira Salazar tornou-se popular no estrangeiro e o seu nome tão conhecido e repeitado como um dos maiores estadistas da actualidade, que não é raro chegarem notícias até de homenagens que, espontaneamente, os estrangeiros lhe prestam", apunta el Diário de Notícias, poco después e

\footnotetext{
${ }^{34}$ Idem, $n^{\circ} 2025$, o6/12/1936, pp. 1 y 7.

35 Idem, n ${ }^{\circ} 2063,16 / 01 / 1937$, p. 1.

${ }^{36}$ Idem, 2127, 23/03/1937, p. 8.

${ }^{37}$ La União Nacional de Porto editó en 1949 un libro que recogía opiniones y testimonios de eminentes personalidades y periodistas de diversos países en la prensa internacional sobre Oliveira Salazar, entre 1928 y 1948. Cf.: Projecção de Salazar no estrangeiro (1928-1948), Porto, União Nacional do Porto, 1949.

${ }^{38}$ Idem, $n^{\circ} 2418,14 / 01 / 19338$, p. 1.
} 
comenzar la guerra en España. ${ }^{39}$ Asimismo, era habitual la reproducción de testimonios de intelectuales o políticos de diferentes países que emitían algún juicio elogioso sobre el líder portugués, cuyo talento político le confería un prestigio inigualable por ningún otro gobernante, según estas versiones. Para el intelectual griego N.G. Politis, amigo personal de António Ferro, el Estado Novo podía muy bien ser el referente fundamental para la construcción de un futuro Estado europeo. ${ }^{40}$ El escritor francés Maurice Maeterlinck, autor del prólogo de la edición francesa de los Discursos de Oliveira Salazar, dirá que aquél estaba "vacinado contra o mal", ya que su espíritu era un "verdadeiro laboratório" de utopías. ${ }^{41}$ Belinda Pogaetsky confirma desde Paris que la "grande obra patriótica" del dictador luso alcanzaba un fama mundial, mientras Raymod Recouly resalta su discrección y sinceridad a pesar de todo. ${ }^{22}$ Pierre Gaxotte remacha diciendo que es "uma das mais nobres figuras e dos mais profundos pensadores da nossa época!” ${ }^{33}$ Era el guía que conducía a su pueblo por el camino correcto. Nada en él era imperfecto y, cuando hablaba o actuaba, lo hacía por el bien de todos. "Quando dizemos que fala Portugal não nos servimos apenas duma metáfora; porque quando fala Salazar fala Portugal e quando Portugal fala - o ouvem (...)".44

Para silenciar las críticas que dirigían muchos intelectuales o periódicos de los países democráticos europeos a Salazar por la vulneración de la neutralidad en el conflicto y su descarado apoyo a los rebeldes españoles, los diarios situacionistas los desautorizaban catalogando esos comentarios como propaganda comunista. ${ }^{45}$ Esta mitificación del dictador portugués, cuyo nombre era utilizado para bautizar bibliotecas en la universidad, ${ }^{46}$ aviones, ${ }^{47}$ escuelas militares ${ }^{48}$ o trofeos deportivos, ${ }^{49}$ se realizó a partir de las informaciones sobre el supuesto reconocimiento público que le tribu-

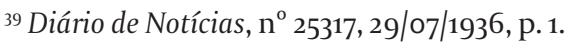

${ }^{40}$ Diário de Lisboa, $\mathrm{n}^{\circ}$ 5042, 29/11/1936, p. 4.

${ }^{41}$ O Século, ${ }^{\circ}$ 19739, 01/03/1937, p. 1.

${ }^{42}$ Diário de Notícias, $\mathrm{n}^{\circ}$ 25523, 26/02/1937, p. 1.

${ }^{43}$ Diário da Manhã, nº 2386, 11/12/1937, p. 1.

${ }^{44}$ Idem, n ${ }^{\circ} 2218,24 / 06 / 1937$, p. 1.

${ }^{45}$ O Século, $\mathrm{n}^{\circ}$ 19707, 26/01/1937, p. 1.

${ }^{46}$ O Primeiro de Janeiro, ${ }^{\circ}$ 115, 26/04/1938, p. 1; O Século, n 19799, 30/04/1937, p. 1. La "Sala Salazar" de la Universidad de Porto recibió importantes aportaciones bibliográficas de la embajada alemana e italiana.

${ }^{47}$ Diário da Manhã, n ${ }^{\circ}$ 2227, 03/04/1937, p. 1.

${ }^{48}$ Idem, $^{\circ}{ }^{2} 285$, 04/07/1938, p. 6.

${ }^{49} \mathrm{Idem}, \mathrm{n}^{\circ} 2612,31 / 07 / 1938$, p. 8.
} 
taban individualidades, instituciones o medios de comunicación extranjeros. Las noticias de homenajes, tanto dentro como fuera de Portugal, a la figura de Oliveira Salazar eran permanentes entre 1936 y 1939. Entre otras distinciones, Salazar fue nombrado doctor Honoris Causa por la Universidad Católica de Fordham, en Estados Unidos, en junio de $193^{8^{\circ}}$ y socio honorario del Instituto dos Advogados Brasileiros un año antes..$^{51}$ Sus méritos eran apabullantes y su forma de gobernar un ejemplo a seguir.5 "(...) A Nação tem plena confiança na inteligência e na acção no sr. Presidente do Conselho porque conhece e aprecia os frutos abundantes e ricos da sua política constructiva; o estrangeiro admira e respeita a sua obra porque ela representa a prova concludente de que as nações são sempre curáveis desde que sejam bem governadas (...)" ${ }^{53}$ Y Portugal era un país sano en una Europa "enferma" gracias a los milagros de su dictador, según el Diário de Notícias. ${ }^{54}$ Opinión que el escultor danés Jean Ganguin lleva incluso más lejos afirmando que la nación peninsular era "o pais mais feliz da Europa" ${ }^{55}$ Pero estos comentarios tuvieron, en algunos casos, la respuesta del reviralho en forma de amenaza por carta. El director del Diário de Notícias, Eduardo Schwalbach, recibió uno de estos anónimos mensajes por la actitud aduladora de su periódico con el Presidente do Conselho.

“(...) O seu pasquim até mete nojo. Não se pode ser mais baixo nem mais miseravelmente adulador. Se os artigos não vêm firmados por você, são contudo, da sua responsabilidade. Nunca vi incensar tão servilmente. Pasmo do cinismo de que dá provas. Afinal quem é o Salazar? Um astucioso como qualquer outro. Que tem ele que outro não fizesse? Nada. Absolutamente nada. Vocês os aduladores mesquinhos são uns canalhões, mas talvez não venha tarde o tempo em que se hão-de retratar como qualquer trânsfuga. As babuseiras que você tem publicado só servem para aumentar o ódio e indignação daqueles que não sabem rastejar aos pés de qualquer ambicioso astuto. Tome cuidado com o futuro, que talvez se arrependa..." ${ }^{6}$

${ }^{50}$ Idem, ${ }^{\circ}{ }^{2573, ~ 22 / 06 / 1938, ~ p . ~} 1$.

${ }^{51}$ Idem, no 2207, 13/06/1937, p. 1.

${ }^{52}$ Diário de Notícias, $\mathrm{n}^{\circ}$ 25325, 06/08/1936, p. 1.

${ }_{33}$ Diário da Manhã, nº 2065, 18/01/1937, p. 1.

${ }^{54}$ Diário de Notícias, ${ }^{0}$ 26252, 11/03/1939, p. 1.

${ }^{55}$ Idem, ${ }^{\circ}{ }^{2}$ 25436, 26/11/1936, p. 2.

${ }^{56}$ AOS/ANTT (Arquivo Oliveira Salazar/Arquivos Nacionais Torre do Tombo), CO/PC-3G, Carpeta $\mathrm{n}^{\circ} 1,4^{\mathrm{a}}$ subdivisión, hojas $\mathrm{n}^{\circ} 11$ y 12 . Carta anónima enviada al director del Diário de Notícias, 09/07/1937. 
La prensa portuguesa jugó con el desequilibrio del contraste con respecto a España para ganarse el agradecimiento popular a un líder que había transformado y engrandecido Portugal. El comentario publicado por J. A. en el Diário da Manhã el 8 de octubre de 1936 era tan tópico como irrefutable: “(...) Enquanto a Espanha percorre, com glória amarga, à custa de mil vítimas e de mil catástrofes, a via dolorosa da Reconquista - Portugal segue a sua marcha, dia a dia mais segura e feliz, na vanguarda das nações de Europa. O Estado Novo representou para nós economia magnífica de muitas revoluções - ou, talvez, do pior de tudo: da guerra civil. Bastar-nos-á o sofrimento da Espanha actual para compreendermos o valor extraordinário deste benefício." ${ }^{57}$ Por eso, Augusto Lima Júnior, en el mismo momento crítico, pedía, desde el Diário de Lisboa, la solidaridad de los portugueses con Salazar, "sentinela da civilização crista na península ibérica”..$^{8}$ “(...) Não acredito que haja um único português, seja qual fôr o seu matiz político ou doutrinário, que não esteja integralmente identificado com o governo da sua pátria, nestes dias em que a torpeza bolchevista procura aviltar o nome eterno de Portugal. Haverá um único português que a esta hora não esteja solidário com Salazar? Não! Não acredito na existência de portugueses sem vergonha", decía el periodista luso.59 Las pruebas de adhesión a la dictadura eran constantes. En la prensa portuguesa o por medio de manifestaciones que tenían una amplia cobertura informativa, Oliveira Salazar fue entronizado como el gran salvador, no sólo como el hombre que había evitado al país de un cruenta guerra civil como la española, sino también el hombre que había colocado a Portugal entre las naciones más poderosas del mundo. En definitiva, el "jefe" portugués, al que, cada año, se le rendían homenajes en el aniversario de su llegada al poder, el $27 \mathrm{de}$ abril,${ }^{60} \mathrm{o}$ durante las conmemoraciones del golpe de Estado, el 28 de mayo, ${ }^{61}$ era, según el intelectual franquista español Eugenio Montes, el ejemplo a seguir por España. ${ }^{62} \mathrm{Y}$ el escritor falangista Maurício Karl, apunta que, al margen de las diferencias lógicas de cada nacionalidad, España debía seguir los pasos de la Revolução Nacional portuguesa. Karl se

\footnotetext{
${ }^{57}$ Diário da Manhã, ${ }^{\circ}$ 1966, o8/10/1936, p. 1.

${ }^{58}$ Diário de Lisboa, ${ }^{\circ}$ 4998, 16/10/1936, p. 2.

${ }^{59}$ Idem, ibídem.

${ }^{60}$ Cf.: Diário de Notícias, ${ }^{\circ}$ 25583, 27/04/1937, p. 1.

${ }^{61}$ El Diário da Manhã publicó en la celebración de 1938 un suplemento especial dedicado a la Revolução Nacional de 156 páginas. Cf.: nº 2548, 28/05/1938.

${ }^{62}$ O Século, n ${ }^{0} 19813,15 / 05 / 1937$, p. 6.
} 
hace cargo de lo mucho que su país debía al Portugal de Salazar, ${ }^{63}$ por el que el presidente de Renovación Española, Antonio Goicoechea, también expresa su más profunda admiración. ${ }^{64}$

El director del SPN, António Ferro, en el prefacio a la edición alemana de uno de sus libros de propaganda, reconoció en 1938 la influencia fundamental de la guerra en la fama y carisma de Olvieira Salazar, que consiguió crear la unidad de la sociedad portuguesa gracias al peso de su figura (sic):

“(...) Creio não me enganar se afirmo que a revolução espanhola e a guerra civil muito contribuiram para a união de todos os portugueses em volta do seu Chefe Salazar, e para a consolidação do regime por ele creado. (...) Portugal não tem, lembremo-nos disso, nenhuns outros vizinhos além dos espanhóis ; está isolado entre a Espanha e o oceano. Sente carregar sobre si todo o peso do poderio espanhol, do qual se desligou politicamente desde o fim do século XI, e esse é o poderio de um grande país. Lembremonos disso, pois há certos factos e certos números que sempre devemos ter diante dos olhos. Portugal é cinco vezes e meia menor do que a Espanha; a Espanha conta 22 milhões de habitantes e Portugal seis milhões e meio. (...) O exemplo da Espanha e a conspiração comunista, que felizmente falhou, prestaram a Portugal e ao seu Chefe um enorme serviço de ordem nacional e moral. Não puzeram apenas um fim à oposição e não estimularam apenas os hesitantes, mas mostraram ainda em que elevado grau foi Salazar um homem previdente, quão necessárias foram as suas reformas e que lance extraordinariamente feliz não significava para Portugal ter conseguido levar a cabo a sua reconstrução nacional antes da implantação da república na Espanha (...)" ${ }^{65}$

La propaganda política portuguesa, además, hace de Portugal un auténtico modelo para la España del general Franco, quien también reconocía, en una entrevista concedida a Augusto de Castro para el Diário de Notícias al finalizar la guerra, que era un admirador de Oliveira Salazar. ${ }^{66}$ Declara-

\footnotetext{
${ }^{63}$ O Século, n ${ }^{\circ} 19556,24 / 08 / 1936$, p. 5 .

${ }^{64}$ Diário de Lisboa, $\mathrm{n}^{\circ}$ 5070, 30/12/1936, p. 4.

${ }^{65}$ AOS/ANTT, CO/PC-12, Pasta $n^{\circ} 1,19^{\text {a }}$ subdivisión, hojas n ${ }^{\circ}$ 47-52. "Actividade informativa e de propaganda do Secretariado de Propaganda Nacional (1933-1943). Prefacio de António Ferro a la edición alemana de uno de sus libros, sin especificar (1938).

${ }^{66}$ Cf.: Correspondência de Pedro Teotónio Pereira para Oliveira Salazar (1931-1939), Lisboa, Presidência do Conselho de Ministros, vol. I, 1987, anexo n ${ }^{\circ}$ 4, p. 241.
} 
ción que era la confirmación de otras afirmaciones suyas anteriores en las que mostraba su intención de construir en España un Estado parecido al portugués. ${ }^{67}$

\section{Franco, el aventajado discípulo del dictador portugués}

De un modo genérico se puede decir sin temor a ser excesivamente atrevido que la imagen de Franco ${ }^{68}$ que fabrica la prensa lusa se construye a partir de su supuesta devoción por el Estado Novo. El comandante de las fuerzas rebeldes se convierte, así - y con mayúsculas - en el salvador de España, el hombre que había lanzado el grito de guerra para impedir el avance de los "bárbaros" de Moscú con la ayuda de Salazar. Franco era, probablemente, después del Presidente do Conselho, el hombre que estaba más en boca de los periodistas de la prensa salazarista. De las informaciones publicadas por la prensa portuguesa deducimos que su imagen ante la sociedad lusa era la de un triunfador querido por su pueblo. Además de su archipromocionada condición de general más joven de Europa ${ }^{69}$ la prensa lusa lo veía como un hombre cabal con madera de líder, serio pero con sentido del humor, humano, inteligente, responsable y sensible con los problemas de los desfavorecidos. Para que se vea cuán sensible es el oficial español, O Século informa que el general Franco indultó a marineros sediciosos (sic) con el Movimiento, ${ }^{70}$ el Diário de Lisboa nos cuenta que el Generalísimo recorrió los barrios pobres de Sevilla preocupado con las condiciones de vida de los españoles, ${ }^{71} \mathrm{y} A \mathrm{Voz}$ relata, el 9 de junio de 1937, que Franco decidió repatriar a sus respectivos países a los prisioneros de las Brigadas Internacionales, a los que trata humanamente y les muestra lo bien que se vive en la zona sublevada. Éstos, según $A V o z$, se dieron cuenta entonces de que fueron engañados por los "comunistas” para combatir con el bando leal. “(...) Na verdade a repatriação dos prisioneiros apanhados à Brigada Internacional foi um acto de grande inteligência de Franco. Não podia encontrar melhores defensores da sua causa no estrangeiro que

\footnotetext{
${ }^{67}$ Diário da Manhã, no 1940, 12/09/1936, p. 1.

${ }^{68}$ Sobre la imagen mitificada del general Franco durante la Guerra Civil, véanse: Preston, Paul, Franco. "Caudillo de España”, Barcelona, Grijalbo-Mondadori, 2 a edición, 1994, pp. 187-403; Tusell, Javier, Franco en la Guerra Civil. Una biografía política, Madrid, Tusquets Editores, 1992; Rey García, Marta, "La creación de la imagen de Franco y su nuevo Estado en Norteamérica”, in Anuario del Departamento de História, $\mathrm{n}^{\circ}$ 5, Madrid, Universidad Complutense, 1993, pp. 57-69.

${ }^{69}$ Por ejemplo, véase Aç̧ão, año 1, nº 14, 29/08/1936, p. 5.

$7^{\circ}$ O Século, no 19814, 16/05/1937, p. 5.

${ }^{71}$ Diário de Lisboa, ${ }^{\circ}$ 5897, 23/04/1939, p. 2.
} 
esses homens, que certamente esperavam, ao renderem-se, encontrar-se dentro de pouco (...) ante o pelotão executor..." (cursiva en el original), explica el periódico católico..$^{72} \mathrm{Su}$ rostro ocupaba frecuentemente un espacio entre las páginas que la prensa portuguesa dedicaba a la guerra, cuyos pies lo encumbraban como el militar más ilustre de Europa.73

Las cualidades militares y políticas del Generalísimo no dejaban lugar a dudas para los medios de comunicación portugueses. Reunía todas las características de un "Jefe” para España, un país en manos de la anarquía y la violencia del comunismo que necesitaba aplicar el modelo portugués. Nadie como el Generalísimo conocía su país y sabía cómo devolverle la gloria de otros tiempos, tal y como había hecho el dictador de Coimbra en Portugal.74 La prensa portuguesa lo veía como un ser predestinado para dirigir el resurgimiento de España siguiendo el camino de Salazar. No en vano, el perfil biográfico que se trazaba del general Franco era bastante parecido al del Jefe del Estado Novo: austero, no fuma ni bebe, puntual, completamente sumergido en su trabajo, culto, gran lector y orador... ${ }^{75}$ Las noticias que hablaban de su carisma y veneración entre la población española lo catapultaban, definitivamente, al Olimpo de los elegidos para gobernar durante largos años. ${ }^{76}$ Con cierta frecuencia, las publicaciones lusas, informaban sobre aclamaciones populares al Caudillo.77 Cada vez que iba al frente recibía el aplauso de todos..$^{8}$ El "libertador" de España era una especie de Mesías que trabajaba en silencio y sin pausa por el "bien" de todos. Su rectitud y seriedad, no le impe-

\footnotetext{
${ }^{72}$ A Voz, ${ }^{\circ}$ 3696, 09/06/1937, p. 1.

${ }^{73}$ Diário da Manhã, n 2181, 18/05/1937, p. 1. Pie de foto: "Nas povoações libertadas, os espanhois de amanhã saudam Franco - o primeiro vencedor no Mundo do bolchevismo nos campos de batalha" (dos niños saludando una imagen de Franco en una pared). Fotos mitificadoras del general Franco las encontramos prácticamente en toda la prensa portuguesa. Por ejemplo véanse: Diário de Notícias, n 25308, 20/07/1936, p. 1; O Século, nº 19600, o8/10/1936, p. 5; Alerta, ${ }^{\circ}{ }^{\circ}$, mayo de 1938, p.13; Defesa Nacional, ${ }^{\circ}$ 61, mayo de 1939, p. 7; Arquivo Nacional, $\mathrm{n}^{\circ}$ 253, 11/1171936, p. 307; Alma Nacional, $\mathrm{n}^{\circ}$ 1, febrero de 1937, série II, p. 28, entre otras muchas. Algunas de sus fotos incluso estaban autografadas con una dedicatoria para los lectores portugueses: cf.: Diário de Notícias, ${ }^{\circ}$ 25.331,12/08/1936, p. 1 . ${ }^{74}$ Idem, $^{\circ}{ }^{\circ} 871,28 / 03 / 1939$, p. 1.

${ }^{75}$ Diário da Manhã, n ${ }^{\circ}$ 1991, 02/11/1936, p. 1.

${ }^{76}$ O Século, $\mathrm{n}^{\circ} 20014,04 / 12 / 1937$, p. 5.

77 O Século, n 19597, 04/10/1936, p. 1. O Século informa que en Vigo se realizó una "grande manifestação” en honor al general Franco. Durante la celebración, el personal que trabajaba para El Pueblo Galllego entregó al comandante militar de la ciudad olívica 720'70 pesetas como resultado de una suscripción interna para el ejército "salvador". O Século, 19850, 21/o6/1937, p. 4.

${ }^{78}$ Comércio do Porto, ${ }^{\circ} 33,04 / 02 / 1937$, p. 1.
} 
dían, sin embargo, emocionarse en medio de las multitudes con cada nuevo éxito militar. ${ }^{79}$ Su prestigio no tenía límites y, por eso, le rendían homenajes incluso los musulmanes. ${ }^{80}$ Según informa $A$ Voz en abril de 1937, 1200 peregrinos llegaron a Sevilla desde la Meca para rezar por el líder de los rebeldes. El pintor Jorge Colaço no desaprovecha la ocasión para alzar al Generalísimo al pedestal de la gloria:

“(...) Para que esses mil e duzentos peregrinos, esquecendo lutas, tradições e preconceitos religiosos, e arrostando, pelo menos, com o desprezo com que certamente seriam recebidos na sua terra em circunstâncias normais, venham da Méca a Sevilha homenagear um chefe cristão, é preciso estarem bem convencidos de que o generalíssimo espanhol, mais do que o seu valor militar incontestado, possui as três virtudes com que um chefe cristão pode convencer um moiro: uma firmeza absoluta de convicções religiosas; um insofismável espírito de justiça, e um alto sentimento de bondade. O gesto desses mil e duzentos peregrinos vindos da Méca, que neste caso traduzem o sentir de milhares de moiros da zona espanhola de Marrocos, é um testimonio evidente do altíssimo prestígio do generalíssimo espanhol, e explica o motivo porque as tropas moiras, junto dos nacionalistas, como eles, lutam e morrem pela Espanha. Enquanto essas três virtudes exemplificadas pelo generalíssimo Franco, penhor da redenção de Espanha, forem para os moiros o que parece indicar, o gesto singular dos peregrinos, as intrigas e as insidias dos inimigos da zona espanhola de Marrocos, serão como a espuma do mar que se desfaz aos pés das suas fortalezas". ${ }^{81}$

El general Franco estaba, pues, por encima del bien y del mal. Su liderazgo y sus incuestionables virtudes parecían otorgarle el mismo estatus social que el dictador portugués, a quien la prensa lusa veía como “(...) a voz da razão num Mundo que teima enlouquecer", según la expresión del Diário da Manhã. ${ }^{82}$ Cuando acabó la guerra, el dictador portugués y el Generalísimo fueron vitoreados como los grandes "salvadores" de la Península Ibérica. El Presidente de la Câmara Municipal de Porto, Mendes Corrêa, así lo declaró públicamente en el consulado de España durante un acto conmemorativo

79 O Século, 19850, 21/06/1937, p. 4.

${ }^{80}$ A Voz, $\mathrm{n}^{\circ} 3644,17 / 04 / 1937$, pp. 1 y 6.

${ }^{81}$ Ibídem.

${ }^{82}$ Diário da Manhã, nº 2124, 20/03/1937, p. 1. 
de la victoria franquista: "Levantemos bem alto os corações neste dia de Festa para Espanha e para Portugal. Venceu por fim a Verdade contra a Mentira. Venceu por fim e para sempre a Honra contra o crime. Venceram os Bons contra os maus. Nesta hora de glória e de vitória resplandecente, ergamos muito alto e através de todo o mundo a nossa saudação e a nossa homenagem a duas figuras salvadoras: a Franco e a Salazar (....)." ${ }^{3}$

El poeta portugués Joaquim Monteiro, admirador del general español envió a la embajada de los agentes rebeldes en Lisboa un extenso põema en el que pide a los españoles que se arrodillen y rezen por su Jefe, que, según él, los estaba salvando del cãos más absoluto. ${ }^{84}$ Franco significada el orden, la cordura y la bondad. Era el "(...) novo Cid para a cruzada da reconquista (...), según el Diário de Notícias. ${ }^{85}$ Los versos de Monteiro lo ensalzaban hasta el punto de santificarlo sin el más mínimo rubor:

“(...)

Podeis erguer um monumento

A Franco restaurador

Foi quem salvou a Espanha

Com auxilio do Senhor;

Defendeu seu nobre povo

Este santo salvador.

(...)

Entregai ao vosso Franco

O destino da Nação

Porque Franco sempre teve

Brioso juizo são;

Podeis deste confiar

O que está em vossa mão.

$(\ldots)^{m 66}$

${ }^{8}$ O Primeiro de Janeiro, $\mathrm{n}^{\circ} 85,29 / 03 / 1939$, p. 1 .

${ }^{84}$ AGA, Exteriores, caja n ${ }^{\circ}$ 6641, "Poesias dedicadas ao Grande FRANCO", de Joaquim Monteiro.

${ }^{85}$ Diário de Notícias, $\mathrm{n}^{\circ}$ 26270, 29/03/1939, p. 1 .

${ }^{86}$ Idem. Hubo otros poetas que le dedicaron põemas al general Franco. Freitas Soares, por ejemplo, publicó los siguientes versos titulados "Fé e patriotismo": "Quando um bom comandante como Franco/Como esse heroi general,/Chefe do Estado espanhol/ - Admirado em Portugal -/ Que os nacionalistas num arranco,/ Guiados por doirado sol,/ Proclamaram com fé e patriotismo,/ Toma o supremo comando/É mais que certo 
Estos versos pertenecen a una extensa oda de 28 estrofas. Algunos de sus pasajes son tan exagerados que no es fácil leerlos sin sentir una cierta sensación de ridículo. Sin embargo, si atendemos a las informaciones que los periódicos portugueses más importantes publicaban sobre el Caudillo español, resulta comprensible su sedución por el personaje y el devoto tono poético hacia el general Franco, un líder que seguía la senda de Salazar, que también tenía quien le dedicase $\operatorname{libros}^{87}$ y poemas en la prensa lusa. En este sentido, Freitas Soares, que escribía en la sección poética de la revista Aviz, había hecho de Salazar y Franco sus principales motivos de inspiración. ${ }^{88} \mathrm{La}$ poesía era, por tanto, también un terreno abonado de propaganda.

que o brutal abismo/ Por onde a Espanha ia resvalando/ Há-de ser bem entulhado/ Com a horda peçonhenta dos traidores/Que em dia amaldiçoado/Espalharam as mais purgentes dores!...". Cf.: Soares, Freitas, Epopeia de Toledo, Lisboa, edición del autor, 1936, p. 27.

${ }^{87}$ La bibliografía sobre la obra y la vida de António de Oliveira Salazar entre 1936 y 1939 es muy abundante. Sobre este aspecto consúltese el artículo citado más atrás de Heloisa Paulo. Véanse también, entre otras las obras originales de Júnior, Costa, Portugal de Salazar, Angra de Heroismo, Tipografia Andrade, 1938; Mendonça Filho, Zuzarte de, Avé, Salazar, Lisboa, Oficinas Gráficas da Rua do Século, 2 a edición, 1939; Brochado, Costa, Salazar e "A Verdade", Porto, Livraria Educação Nacional, 1937; Andrade, J. Gonçalves, Doutor Oliveira Salazar-O seu Tempo e a sua Obra, Porto, Educação Nacional, 1937; Moscoso, António Salazar (cónsul general de Portugal en Chile), El 5 de octubre de 1937 en Santiago de Chile. Charla transmitida por la estación de radio Hucke por el Cónsul General de Portugal, Santiago de Chile, Editorial Nascimento, 1937; Paixão, Osvaldo, Salazar e salazarismo, Rio de Janeiro, Schmidt Editor, 1939; Pereira, Pedro Teotónio, O espírito da gente nova na Revolução Nacional, Lisboa, Secretariado de Estado das Corporações e Previdência Social, 1937; Faria, Américo de, Salazar. Revolução Nacional (1926-1937), Lisboa, Gráfica Moderna-Coruche, 1937; Ferro, António, Homens e Multidões, Lisboa Livraria Bertrand, 1938; Anselmo, Manuel, Antologia Moderna. Ensaios críticos, Lisboa, Livraria Sá da Costa Editora, 1937 (contiene un capítulo sobre la figura de Salazar como intelectual y escritor, pp. 15-21); Salazar, António Oliveira de, O Salazar definido por si mesmo (entrevista publicada en el Daily Telegraph y el el Diário de Notícias), Santiago de Chile, Editorial Nascimento, 1937; idem, Alocução proferida Por Salazar em 11 de Maio de 1938 aos legionários de Portugal, Lisboa, s.l., 1938; Teixeira, Luis, Perfil de Salazar, Lisboa, edición del autor, 1939. ${ }^{88}$ Aviz, año I, nº 1, marzo de 1938, "Secção Poética", s.p.; idem, nº 2, abril de 1938. 


\section{ANEXO FINAL: LAS 60 MÁXIMAS POLÍTICAS DE SALAZAR \\ DEL “GRANDE CONCURSO NACIONAL”, ORGANIZADO POR LA EMISSORA NACIONAL Y EL DIARIO DA MANHÃ EN MARZO DE 1937.}

Numeradas por orden de publicación, la relación es la siguiente:

$\mathrm{N}^{\mathrm{o}}$ 1: "Nada contra a Nação, Tudo pela Nação". n ${ }^{\circ}$ 2: "Temos obrigado de sacrificar tudo por todos; não devemos sacrificar-nos todos por alguns"; n ${ }^{\circ} 3$ : “Não há Estado forte onde o Poder Executivo o não é, e o enfraqucimento deste é característica geral dos regimes políticos dominados pelo liberalismo individualista ou partidário e pelos excessos e desordens do parlamentarismo"; n 4: "Os homens que se habituam a cumprir sempre e só o seu dever pouco se lhes dá do lugar que ocupam; interessa-lhes muito desempenhá-lo bem”; nº 5: "Se a Fé não é uma mentira, será fonte inesgotável de vida espiritual; mas, se como virtude e dom de Deus, nem compreendemos que se imponha pela força nem a vantagem de se contrariar a sua prática"; Frase $n^{\circ}$ 6: "Os portugueses que se aprestem a oferecer o seu concurso sabem que cumprem um dever, mas não adquirem um direito, e que precisamente com a sua ajuda é que Estado vai deixar de fazer favores a alguns para poder distribuir justiça a todos"; $n^{\circ}$ 7: "É timbre do Governo não prometer - realizar; não começar - fazer"; n 8: "A universalidade de idea e de acção no curso da evolução católica e europeia, dirigida à elevação material e moral da espécie, eis a característica da história da nossa Pátria”; ${ }^{\circ}$ 9: "Por mais longe que vá a nossa tolerância perante as divergências doutrinais que em muitos pontos dividem os homens, nós somos obrigados a dizer que não reconhecemos liberdade contra a Nação, contra o bem-comum, contra a família, contra a moral”; n 10 "Nós temos uma doutrina e somos uma força. Como força compete-nos governar: temos o mandato duma revolução triunfante, sem oposições e com a consagração do País; como adeptos duma doutrina, importa-nos ser intransigentes na defesa e na realização dos princípios que a constituem”; n $^{\circ}$ 11: Na vida pública como na particular a falta de sinceridade desgosta e cansa: nenhum regime político que use a mentira como método de governo ou se contente de verdades convencionais pode acreditar-se na alma popular"; n ${ }^{\circ}$ 12: "O comunismo é, como sistema e independentemente de algumas realizações materiais, a síntese de todas as revoltas tradicionais da matéria contra o espírito e da barbária contra a Civilização. Ele é a grande "heresia" da nossa idade”; $n^{\circ}$ 13: “O plutocrata não é nem o grande industrial nem o financeiro: é 
uma espécie de híbrida intermediária entre a economia e a finança; é a "flor do mal" do capitalismo"; $\mathrm{n}^{\circ}$ 14: "Nenhum povo no Mundo pode amar mais Portugal do que os portugueses, nem instituição ou Governo pode haver que melhor os defenda do que o Governo da Nação"; n ${ }^{\circ}$ 15: "Tem muita força quem tem razão e quem não dá contra si mesmo razão aos outros"; ${ }^{\circ}{ }^{16}$ : "Para elevar e robustecer, engrandecer as nações é preciso alimentar na alma colectiva as grandes certezas e contrapor às tendências de dissolução propósitos fortes, nobres exemplos, costumes morigerados; $\mathrm{n}^{\circ}$ 17: "É impossivel valer socialmente tanto o que edifica como o que desmoraliza, os criadores de energias cívicas ou morais e os sonhadores nostálgicos do abatimento e da decadência"; $\mathrm{n}^{\circ}$ 18: "Portugal não perturba a paz do Mundo nem a ninguém pode permitir que perturbe a sua"; ${ }^{\circ}$ 19: "Nenhum de nós - nacionalista e amante do seu País - faz profissão de nacionalismo agressivo, exclusivo, odioso, antes, se se (sic) apega à noção de pátria, é que compreende, por instinto do coração e por imposição da inteligência que o plano nacional é ainda o melhor para a vida e os interesses da humanidade"; $\mathrm{n}^{\circ} 20$ : "Na organização das corporações económicas deve ter-se em vista que os interesses por ela prosseguidos, ou melhor, os interesses da produção, têm de subordinar-se não só aos da economia nacional no seu conjunto, mas também à finalidade espiritual ou destino superior da Nação e dos indivíduos que a constituem"; ${ }^{0}$ 21: "Demos à Nação optimismo, alegria, coragem, fé nos seus destinos; retemperemos a sua alma forte ao calor dos grandes ideais, e tomemos como nosso lema esta certeza inabalável: Portugal pode ser, se nós quisermos, uma grande e próspera Nação"; $n^{\circ}$ 22: "Por cima da negação do que há de mais evidente e palpável na nossa obra brilhará sempre o despertar da consciência nacional, o prestígio de Portugal no Mundo: por toda a parte o orgulho de ser português remoça o sangue dos portugueses de hoje e permite repousem tranquilas no túmulo as cinzas heroicas dos portugueses de ontem"; n ${ }^{\circ}$ 23: "Agora, como em todos os momentos críticos, é preciso escolher, saber escolher e saber sacrificar - o acidental ao essencial, a matéria ao espírito, a grandeza ao equilíbrio, a riqueza à aquidade, o desperdício à economia, a luta à cooperação"; $\mathrm{n}^{\circ}$ 24: "Nós queremos caminhar para uma economia nova (cursiva original), trabalhando em unísono com a natureza humana, sob a autoridade dum Estado forte que defenda os interesses superiores da Nação, a sua riqueza e o seu trabalho, tanto dos excessos capitalistas como do bolchevismo destruidor"; $n^{\circ} 25$ : "Há alguns anos que já a nossa política deixou felizmente de ser o reflexo de dous ou três outros países. A experiência feita tem demonstrado que a hora não é das direitas nem das 
esquerdas: a hora é de quem sabe o que quere e quere na verdade realizar o seu ideal político"; n ${ }^{\circ}$ 26: "Quando estivermos bem compenetrados de que a aliança com a Inglaterra não é nem uma tutela nem uma fiança da nossa acção política interna ou externa, não recearemos as atitudes equívocas ou subservientes nem a deminuição da nossa acção internacional, antes havemos de trabalhar por valorizar ao máximo aquele apreciável instrumento político: visto que temos de dar, havemos de saber exigir"; n 27 : "Nós queremos ir na satisfacção das reivindicações operárias, dentro da ordem, da justiça e do equilíbrio nacional, até onde não foram capazes de ir outros que prometeram chegar até o fim"; $n^{\circ} 28$ : "Há uma geração sacrificada ao futuro da Pátria - a nossa geração"; $\mathrm{n}^{\circ}$ 29: "A autoridade é um facto e uma necessidade: só desaparece para se reconstituir, só se combate para a entregar a outras mãos. É um direito e um dever - dever que se nega a si próprio se se não exerce, direito que tem no bem comum o seu maior fundamento. É ainda um alto dom da Providência, porque sem ela nem seria possível a vida social nem a Civilização humana”; $\mathrm{n}^{\circ}$ 30: “O nosso espírito está aberto às mais largas reformas no campo económico e social; só fazemos excepção das que desconheçam o princípio da hierarquia dos valores e dos interesses e da mais perfeita conjugação dêstes dentro da unidade nacional"; $\mathrm{n}^{0}$ 31: "A riqueza, os bens, a produção não constituem em si próprios fins a atingir; têm de realizar o interesse individual e o interesse colectivo; nada significam se não estão condicionados à conservação e elevação da vida humana"; $n^{\circ} 32$ : "Nenhum bem me parece exceder para as nações a estabilidade de Governos capazes: se a permanência dos nulos se asemelha à estagnação, é ainda pior o rápido desfile de sumidades com seus farrapos de ideas e planos e seus empurrões descompassados na máquina governativa"; $n^{0}$ 33: "Há na vida das sociedades modernas uma crise mais grave do que a crise da moeda, e dos câmbios, e do crédito, e dos preços, e das finanças públicas, mas grave porque é mâe de todas elas - é a crise do pensamento económico, diremos, a crise dos princípios informadores da vida económica"; $\mathrm{n}^{\circ} 34$ : "A adulação das massas pela criação do "povo soberano" não deu ao povo, como agregado nacional, nem influência na marcha dos negócios públicos, nem aquilo de que o povo mais precisa - soberano ou não - que é ser bem governado"; $n^{\circ} 35$ : "Vamos conseguindo com segurança o método , na sequência da nossa política realista e por meio da nossa organização corporativa, o que revolucionariamente não pode ser executado ainda que prometido, e mais longe iremos ainda, quando pudermos não só anunciar nos discurssos ou inscrever nas leis, mas efectivar, na prática, os dois maiores direitos que ao homem podem ser asse- 
gurados: o direito ao trabalho e o direito à instrução - o pão do corpo e do espírito para todos os portugueses de boa vontade"; $n^{\circ}$ 36: "Advoguei sempre uma política de administração, tão clara e tão simples como a pode fazer qualquer boa dona de casa - política comezinha e modesta que consiste em gastar bem o que se possue e não se despender mais do que os próprios recursos"; n ${ }^{\circ}$ 37: "Só o espírito do mal se agita; só os sem pátria vêem com ódio renascer e abrir a flor do nosso patriotismo, afirmar-se o nosso sentido de Nação, multiplicarem-se as manifestações do nosso progresso material e moral, consolidar-se a nossa posição no Mundo, estabelecer-se a paz interna pela Justiça; só os falsos profetas reincidem nas promessas que nunca cumpriram e encarecem despudoradamente muitas outras que não poderiam ser cumpridas"; $\mathrm{n}^{\circ}$ 38. "A nossa posição relativamente ao comunismo está fixada e em relação aos comunistas também. Contrariamente ao que ele faz não vamos combate-lo em parte alguma, mas aqui não consentiremos que nos escravize a nós. Esta política de bondade e tolerância tem nas fronteiras e no interior o limite imposto pela salvação comum, e esse em caso algum será desrespeitado; $\mathrm{n}^{\circ}$ 39: "Nós e a Espanha somos dois irmãos, com casa separada na Península, tão vizinhos que podemos falar-nos das janelas, mas seguramente mais amigos porque independentes e ciosos da nossa autonomia"; $\mathrm{n}^{\circ}$ 40: "O Estado não deve ser o senhor da riqueza nacional em colocar-se em condições de ser corrompido por ela. Para ser árbitro superior entre todos os interesses é preciso não estar manietado por alguns"; n ${ }^{\circ} 41$ : "Não há sindicato onde não existe espírito corporativo, consciência do valor do trabalho e do lugar que ocupa no conjunto da produção, compreensão da necessidade de cooperar com todos os outros factores para o progresso da economia nacional. Onde tais qualidades não existem, mas só o espírito da luta de classe, não temos verdadeiramente o sindicato, temos a associação revolucionária, a força ao serviço da desordem"; $\mathrm{n}^{\circ}$ 42: "Quem é contra a Nação não pode ser militar"; $n^{\circ} 43$ : "O Estado Novo deve ser bem forte e resistente para dominar as correntes revolucionárias, assegurar a unidade nacional, coordenar a actividade de todos os elementos, enfim, empreender e fomentar a verdadeira revolução que tem de ser esboçada por estas gerações e prosseguida pelas que lhe sucederem"; ${ }^{\circ}$ 44: "Se muitos homens não disporem para viver de mais nada senão do potencial do seu trabalho, duas conclusões se impõem: uma é que é preciso organizar a economia nacional de modo a terem trabalho os trabalhadores; outra é que o trabalho tem de ser regulado e organizado por forma que o salário permita aos trabalhadores viver"; $\mathrm{n}^{\circ} 45$ : "A herança é o reflexo na propriedade do instinto de perpetuidade da raça; 
transmite-se com o sangue o fruto do trabalho, da economia, quantas vezes de grandes privações”; n 46: “A Nação é para nós uma e eterna; nela não existem classes privilegiadas, nem classes diminuídas. O povo somos nós todos, mas a igualdade não se opõe e a justiça exige que onde há maiores necessidades aí seja maior a solicitude: não se é justo quando se não é humano”; $\mathrm{n}^{\circ}$ 47: "A solidariedade de interesses que está na base da sociedade obriga cada um de nós a contribuir pela inteligência ou pela acção para o património comum: o homem que não trabalha lesa todos os demais"; n 48: "Que pena me faz saber aos domingos os cafés cheios de jovens, discutindo os mistérios e problemas de baixa política, e ao mesmo tempo vêr deserto esse Tejo maravilhoso sem que nele remem e velejem, sob o céu incomparável, aos milhares, os filhos deste País de marinheiros!"; n 49: “A ordem e a perfeita correcção dos processos financeiros são, além de condição essencial do nosso ressurgimento, garantia da independência e integridade da Pátria"; ${ }^{\circ}{ }_{50}$ : "Alheios a todos os conluios, não vendemos, não cedemos, não arrendamos, não partilhamos as nossas colónias, com reserva ou sem ela de qualquer parcela de soberania nominal para satisfacção dos nossos brios patrióticos. Não no-lo permitem as nossas leis constitucionais; e, na ausência destes textos, não no-lo permitiria a consciência nacional"; $n^{\circ}$ 51: "É na verdade com o mesmo critério de Nação, agregado social diferenciado, independente, soberano, estatuindo, como entende, a divisão e organização do seu território, sem distinções de situação geográfica, que nós consideramos, administramos as colónias. Tal qual como o Minho ou a Beira, e, sob a autoridade única do Estado, Angola ou Moçambique ou a Índia. Somos uma unidade jurídica e política, e desejamos caminhar para uma unidade económica, tanto quanto possível completa e perfeita, pelo desenvovimento da produção e intensa permuta das matérias primas, dos géneros alimentícios e dos produtos manufacturados entre umas e outras partes deste todo"; $n^{\circ}{ }^{52}$ : "A vida humana tem exigências múltiplas e é de desejar que cada vez tenha mais. Mas nesta via ascendente de necessidades e de riquezas acumuladas não deve esquecerse que não há progresso quando a vida é mais rica, e só quando é mais alta, mais nobre na sua chama inteiror e na sua projecção externa"; n 53: "Tumultuam à nossa roda bastos egoísmos, vaidades, ambições de mando, sôfregos interesses individuais que não se subordinam e pretendem sobrepor-se aos interesses da colectividade; e há muitos milhares de portugueses que oferecem a sua dedicação ao bem comum, que tomam a defesa deste como dever onde quer que se lhes indique o lugar da acção, trabalhando, obedecendo, servindo (cursiva original): estamos vendo coisas novas em 
Portugal"; $\mathrm{n}^{\circ}$ 54: "Ter bem presente no espírito que os homens vivem em condições difrerentes e que esse facto se opõe, por vezes a que seja uma realidade a sua igualdade jurídica; proteger o Estado de preferência aos pobres e aos fracos; fomentar a riqueza geral para que a todos caiba ao menos o necessário; multiplicar as instituições de assistência e de educação que ajudem a elevar as massas populares à cultura, ao bem estar às altas situações do Estado e da Nação; manter não só abertos, mas acessíveis, todos os quadros à ascensão livre dos melhores valores sociais - isto é amar o povo e, se a democracia pode ter ainda um bom sentido, isto é ser pela democracia"; $\mathrm{n}^{\circ}$ 55: "A revolução do 28 de Maio é vincadamente popular - pela sua preocupação de contacto directo com a alma do povo e de satisfacção das suas instantes necessidades"; n ${ }^{\circ}$ 56: "Portugal é um Estado que ama a paz, tem o espírito civilizador, colabora no fortalecimento da ordem universal, estigmatiza a guerra ambiciosa, perfilha a arbitragem para a liquidação das questões entre os Estados, integra o seu direito público no quadro dos fins superiores da humanidade, e pretende o desenvolvimento harmónico, pacífico, produtivo das faculdades dos cidadãos, para o aperfeiçoamento e progresso das relações internas e externas da Nação"; ${ }^{\circ}$ 57: "Duma civilização que regressa cientificamente à selva separa-nos se remissão o espiritualismo - fonte, alma, vida da nossa História. Fugimos a alimentar os pobres de ilusões, mas queremos a todo o transe preservar da onda que cresce no Mundo a simplicidade de vida, a pureza dos costumes, a doçura dos sentimentos, o equilíbrio das reacções sociais, esse ar familiar, modesto mas digno da vida portuguesa - e, através dessas conquistas ou reconquistas das nossas tradições, a paz social"; $\mathrm{n}^{\circ}$ 58: "Temos em Portugal sacrificado muitas vezes demasiadas coisas a um humanitarismo que desconhece a justiça devida à grande massa inocente, vítima constantemente imolada às fúrias dos que esse humanitarismo absolve. Nós podemos perdoar as penas, mas não podemos esquecer as culpas, e criminosos seríamos não deduzindo dessa generosa atitude a necessidade duma vigilância mais atenta, duma segurança mais firme, e duma repressão mais severa, se factos passados viessem a repetir-se"; $n^{\circ}$ 59: "Nós não compreenderiamos - nós não poderiamos admitir - que a escola, divorciada da Nação, não estivesse ao serviço da Nação, e não compreendesse o altíssimo papel que lhe cabe nesta hora de ressurgimento, na investigação e no ensino, a educar os portugueses para bem compreenderem e bem saberem trabalhar"; $\mathrm{n}^{\circ}$ 6o: "Operamos com prudência e segurança, com o método nosso ja conhecido, uma transformação profunda na essência e na orgânica do Estado; fazemos da vida económica elemento da organização política; 
pomos o trabalho, seja qual fôr a sua forma, entre os conceitos básicos da nova vida social e fazemos guerra a todos os parasitismos, a começar pelo da administração pública; pretendemos ordenar a economia nacional, salvaguardando a iniciativa privada; queremos o nacionalismo em economia, mantendo a benéfica concorrência dos produtores entre si e destes com os dos países estrangeiros; tendemos à organização de todos os interesses para a sua defesa e valorização, mas queremos o Estado suficientemente digno e forte para não ser corrompido por eles, para lhes não permitir que abusem da sua força e para os coordenar em ordem à realização conveniente dos fins superiores dos indivíduos e da Nação". 